\title{
Occupational accidents related to cattle slaughter in Mato Grosso, Brazil
}

\author{
Acidentes de trabalho relacionados ao abate de bovinos \\ em Mato Grosso, Brasil
}

\author{
Ageo Mario Cândido da Silva ${ }^{1,2}$, Alexandre Volkman Ultramari ${ }^{3}$, \\ Walderley Antonio Pginati ${ }^{4}$, Gisele Pedroso $\mathrm{Moi}^{4}$
}

\begin{abstract}
Resumo
Introdução: A criação de gado no sul da Amazônia tem crescido rapidamente, sendo que o Mato Grosso é um dos primeiros estados na produção de carne. Esse crescimento permitiu a contratação de mais trabalhadores para a atividade de refrigeração, trazendo um aumento de acidentes de trabalho nesse setor. Objetivo: Analisar a influência de abate de gado nos acidentes de trabalho e sua distribuição espacial no estado de Mato Grosso, Brasil. Métodos: Estudo ecológico que investigou a autocorrelação espacial global das taxas de acidentes de trabalho e o número de bovinos abatidos em municípios de Mato Grosso, usando a estatística Moran "global" pelo método LISA e, posteriormente, uma regressão múltipla espacial, tendo como variáveis de exposição o abate de cabeças de gado e, como variável resposta, a taxa de acidentes de trabalho. Resultados: Foram encontrados padrões espaciais globais na distribuição do número de cabeças de gado abatidas. Na regressão múltipla, foram observadas correlações estatisticamente significantes entre o número de bovinos abatidos e a taxa de acidentes de trabalho. Conclusão: $\mathrm{O}$ abate de gado está relacionado ao aumento do número de acidentes de trabalho no Estado de Mato Grosso, Brasil.
\end{abstract}

Palavras-chave: acidentes de trabalho; abate de animais; análise espacial.

\begin{abstract}
Introduction: Cattle rising in the southern Amazon have grown rapidly, being Mato Grosso one of the top states in meat production. This growth led to the hiring of more workers to the chilling activity, increasing the number of workplace accidents in this sector. Objective: To analyze the influence of slaughter cattle on occupational accidents and their spatial distribution in the state of Mato Grosso, Brazil. Methods: This is the first ecological study investigating the global spatial autocorrelation of the occupational accident rate and the number of slaughtered cattle in Mato Grosso municipalities; this study used the statistic Moran "global" by LISA method and subsequently held a spatial linear regression, with cattle slaughter exposure variables and as an outcome it showed the rate of workplace accidents. Results: The study showed a global spatial pattern of number of cattle slaughtered. Statistically significant correlations were observed, in multiple regression analysis, between the number of cattle slaughtered and rate of occupational accidents. Conclusion: The cattle slaughter is related to the increase of industrial accidents in the State of Mato Grosso, Brazil. Keywords: occupational injuries; animal culling; spatial analysis.
\end{abstract}

${ }^{1}$ Instituto de Saúde Coletiva, Universidade Federal de Mato Grosso (UFMT) - Cuiabá (MT), Brasil.

${ }^{2}$ Centro de Referência Estadual de Saúde do Trabalhador, Secretaria do Estado de Saúde - Cuiabá (MT), Brasil.

${ }^{3}$ Universidade Estadual de Mato Grosso (UNEMAT) - Cuiabá (MT), Brasil.

${ }^{4}$ Centro Universitário de Várzea Grande (UNIVAG), Várzea Grande (MT), Brasil.

Trabalho realizado no Instituto de Saúde Coletiva (ISC) da Universidade Federal do Mato Grosso (UFMT) - Mato Grosso (MT), Brasil.

Correspondence: Ageo Mario Cândido da Silva - Avenida Antártica, 788, Casa 53 - Bairro Ribeirão da Ponte - CEP: 78040-500 - Cuiabá (MT), Brasil -

Email: ageoms@hotmail.com

Financial support: The authors of this article use own resources for financial support of this research.

Conflict of interests: nothing to declare. 


\section{INTRODUCTION}

The beginning of livestock activities in state of Mato Grosso in the southern Brazilian Amazon, dating back to the late eighteenth century, attracted new migratory flows to the region. Around 1870, with the Paraguayan War, the final (1865-1870) livestock presents a major expansion in the Pantanal area ${ }^{1}$. The twentieth century presented a significant increase in population with deep changes in socio-economic and environmental characteristics of the Amazon region, and in particular, Mato Grosso began to have in agriculture a major economic and job creation potential due to its large territory and amount of land ${ }^{2}$. In the last decade, the cattle ranching in Mato Grosso has grown at a faster rate than the national livestock, putting the state in the top positions in both beef production and in number of cattle ${ }^{3}$.

If on one hand, the meat segment growth led to an increased demand for hand work and hiring workers for slaughterhouses units in various municipalities of the state, on the other hand, the cooling activity exponentially increased the incidence of workplace accidents in this sector ${ }^{4}$. Workers poor qualification, as well as the poor working conditions of this sector, are among the main reasons for these accidents.

This study aimed to analyze the influence of cattle slaughter on occupational accidents and their spatial distribution in municipalities in the state of Mato Grosso, between 2002 and 2008.

\section{METHODS}

This is an ecological study including the 139 existing municipalities in the state of Mato Grosso. Geographic and spatial data for each municipality, considering latitude, longitude, perimeter, area and location of each municipality's seat in the state, were obtained from the website of the Brazilian Institute of Geography and Statistics ${ }^{6}$.

The number of cattle slaughtered was used as exposure variable according to the municipality in the state of Mato Grosso in the years 2002 to $2008^{6}$. The average rate of industrial accidents was used as a variable between 2002 to 2008, when all reported cases of occupational accidents were added through the Work Accident Report - WAR, registered with the National Institute of Social Security?.

The Total number of formal workers that work for the municipality was considered a denominator, provided by the General Register of Employed and Unemployed People GREUP, of the Ministry of Labor and Employment ${ }^{8}$, using the following Formula 1:

$$
\text { IAT }=\frac{\sum \text { Work Accident Report }}{\sum \text { Workers }} \times 10,000
$$

The Gross Domestic Product (GDP) per capita average was considered as adjustments variables in the years 2002 to $2008^{6}$, by the municipality (given that inequalities in education and income indicate different access needs and availability of health services), population percentage registered by the Family Health Program (FHP) ${ }^{9,10}$ in the years 2002 to 2008 (indicates the possibility of access to health services) and Hospital Existence in the City ${ }^{9,10}$ (included as a discrete variable (yes/no), to represent the availability of health services in the city).

\section{Data analysis}

A univariate exploratory spatial data analysis was performed to assess the global spatial autocorrelation of cattle slaughter indicators of labor accident rates in the period from 2002 to 2008 in the municipalities of Mato Grosso, using the Moran's I index under the assumptions of normality and randomization.

The high spatial correlation is indicated by a distribution of the Moran index values ranging between -1.0 and +1.0 and tests, where connected areas have stronger similarity to the studied indicator than expected in a random pattern, with values close to -1.0 and $+1.0^{11}$.

Bivariate analyzes were carried out in a second phase, where the direction and the magnitude of the associations between the independent variables were assessed through a correlation matrix (not shown) followed by the spatial multiple linear regression. This type of analysis has the same assumptions as the traditional linear regression, however it takes into account the spatial trends and correlations of data and, if correlated, certain parameters are incorporated to allow the withdrawal of these effects. The quality of spatial regression model fit is similar to the traditional multiple regression model, and it is verified by the residual analysis ${ }^{12}$.

The exclusion criteria were set by $p$-value greater than or equal to 0.05 . We opted for the maintenance of variable percentage of population served by FHP to better model fit.

The verification of the linear regression assumptions, graphical analyzes of standardized residuals were made based on observed values and predicted beyond the diagnosis of normality through QQ plot graphs. The variables homoscedasticity presented random distribution without cyclical behavior or defined trend. There was no spatial autocorrelation of waste at the final models determination. We used the software Stata 9.1, SPSS 15.0 and GeoDa 0.9.5-i.

The project was submitted for approval by the Institutional Review Board of the University Hospital Research Júlio Müller UFMT in 2010, before the scheduled data collection for December 2010 and was approved in the Opinion 943/2010.

\section{RESULTS}

There was a random distribution of occupational accidents among the municipalities of Mato Grosso, in spite of some clusters in the center of the state (Figure 1). Regarding the cattle slaughter (Figures 2 and 3), there is the occurrence of spatial 
autocorrelations of the "high-high" type, indicating grouping of municipalities with greater cattle slaughter in the Amazon and Pantanal biomes, and the "low-low" type, considered groupings of smaller number of slaughtered heads, located

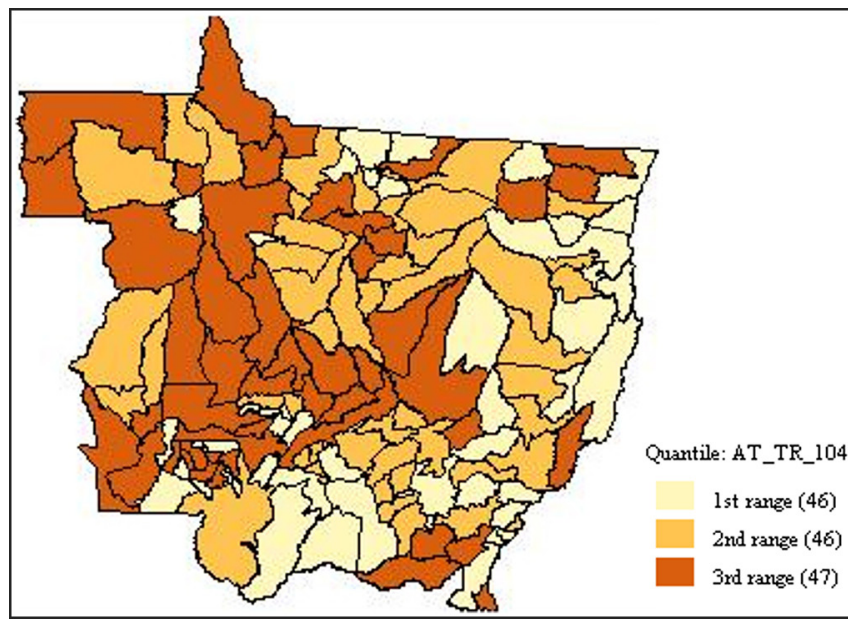

Figure 1. Rate of occupational accident per 10,000 workers in municipalities in the state of Mato Grosso, from 2002 to 2008, according to tertiles

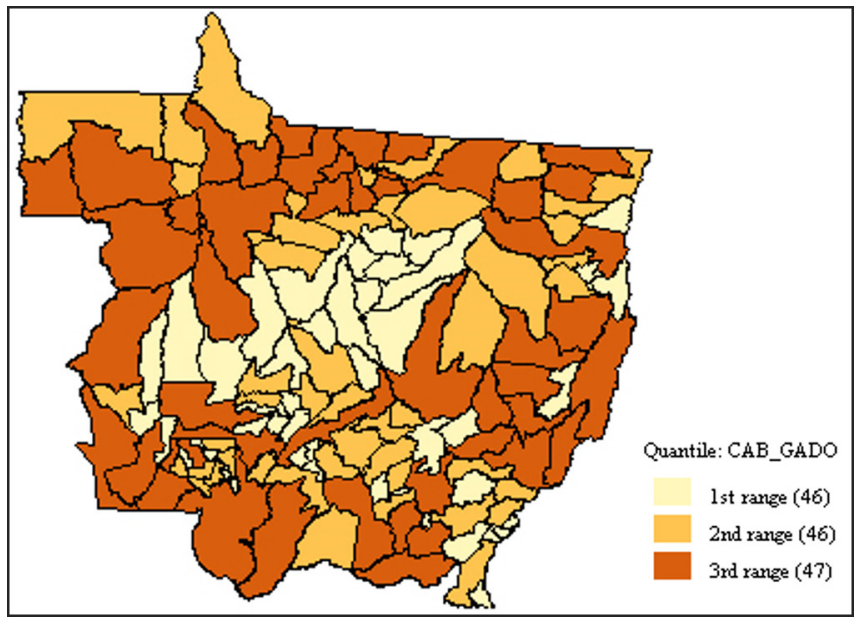

Figure 2. Head of cattle slaughtered in municipalities in the state of Mato Grosso, from 2002 to 2008, according to tertiles

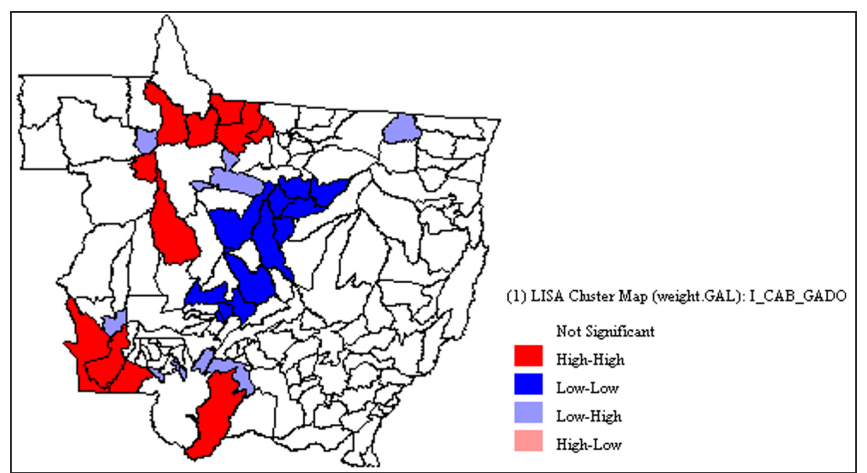

Figure 3. Moran dispersion map for cattle slaughter, Mato Grosso, from 2002 to 2008
Table 1. Space Multiple Regression Models of Empirical Bayesian Estimation of Accident rates recorded by the communication occupational accident (CWA), by 10,000 workers on livestock production and other variables of the model in the municipalities of the State of Mato Grosso between 2002 and 2008

Model Coefficients $\begin{gathered}\text { standard } \\ \text { error }\end{gathered} \quad t \quad p$-value

\begin{tabular}{|c|c|c|c|c|}
\hline \multicolumn{5}{|l|}{$\begin{array}{l}\text { Rate of work } \\
\text { accident (CWA) } \\
\text { per } 10.000 \\
\text { workers }\end{array}$} \\
\hline Hospital & 31.902 & 16.397 & 1.946 & 0.054 \\
\hline $\begin{array}{l}\text { Average per } \\
\text { capita GDP }\end{array}$ & 0.001 & 0.001 & 2.437 & 0.016 \\
\hline $\begin{array}{l}\text { Population ratio } \\
\text { attended by FHP }\end{array}$ & -0.061 & 0.278 & -0.218 & 0.828 \\
\hline $\begin{array}{l}\text { Cattle } \\
\text { slaughtered No. }\end{array}$ & $1.73 \times 10^{-5}$ & 0.001 & 2.465 & 0.015 \\
\hline
\end{tabular}

in municipalities belonging to the Brazilian savanna biome. The statistical Moran was significant $(\mathrm{I}=0.2239$; $\mathrm{p}$-value $<0.001$ for 999 permutations).

Table 1 presents the final model of Multiple Linear Regression Space. There were significant associations among the rate of occupational accidents with GDP per capita $(\mathrm{p}=0.016)$, number of slaughtered cattle $(\mathrm{p}=0.015)$ and statistically significant association bordering the presence of hospitals in the city (0.054).

In the analysis of residues of the multiple linear regression model it was the pattern of absence in the dispersion of waste, Moran test indicating random distributions and lack of spatial autocorrelations. Thus, there is no need to parameter variables, thus justifying up the proper adjustment of the final model.

\section{DISCUSSION}

This study showed a statistical association between cattle slaughter and higher workers' compensation rates in in the state of Mato Grosso. In the past decade, this state intensified livestock through public policies for occupying new areas of savannah and Amazon forest ${ }^{13}$. Increasingly, slaughterhouses were installed in various municipalities for the production of meat products with higher added value and reduction of live animal shipping. Concomitantly, the work activities related to meat production chain have generated an increase of diseases and occupational accidents ${ }^{7}$.

Importantly, despite the increase in jobs, there was a deterioration of working conditions. The production of meat in slaughterhouses in the Amazon region still follows the assumptions of the Taylor-Fordist system focused on production targets and based on the fast pace of work ${ }^{14}$. Operations are sequential as in an assembly line where, the rate is established by the number of animals to be slaughtered in a certain period of time instead of being determined by the individual $\mathrm{it}^{15}$. Thus, 
the requirement of compliance with regulatory standards established by the Ministry of Labour and Employment ${ }^{16}$ are ineffective at reducing these workers risk of diseases and health problems. In addition, the work at the cattle chain still employs many informal workers, excessive working hours, increasing the occurrence of occupational musculoskeletal disorders (MSDs), cut by knives and other occupational health problems ${ }^{4}$.

The positive correlation of GDP and the number of slaughtered cattle indicates that the slaughterhouse activity has a possible positive impact on the economy of Mato Grosso municipalities, especially those belonging to the less developed regions of in the state of Mato Grosso where the slaughtering cattle units were installed. Livestock has brought productivity gains and increased income to localities with large slaughterhouses networks. However, Arima et al. ${ }^{17}$ stated that the production systems are heterogeneous and low-tech. This implies (again) in precarious jobs, which may be related to greater likelihood of accidents at these locations.

The Moran dispersion map shows, beyond the Pantanal, traditional biome for the cattle creation, that the Amazon biome was identified as a high spatial autocorrelation with cattle slaughter. Rivero et al. ${ }^{18}$ showed that the cattle slaughter developed consistently and was accompanied by the expansion of slaughterhouse for the Amazon region, more specifically in Mato Grosso. This same author also concludes that, regarding the land use and deforestation, cattle rising is the most strongly correlated with deforestation activity in the municipalities of the Amazon.

The damage caused by deforestation is immeasurable. Identified as the area of greatest biodiversity on the planet and having $1 / 5$ of the world's fresh water reserves, about $20 \%$ of the original area of the Brazilian Amazon forest is already deforested ${ }^{19}$. In addition to environmental degradation, this deforestation is responsible for one quarter of Brazil's emissions of greenhouse gases ${ }^{20}$.

On the other hand, Silva et al. ${ }^{21}$ states that occupational accidents must not be understood only as an expression of the technologies used in the production process; it must also include labor organization and division, involvement of employees in the workplace and action technicians and institutions regarding health and safety issues. Marques ${ }^{22}$ questions whether the precariousness of labor relations and employment of Brazilian meat is inevitable; fact that is known from mandatory accident prevention programs, Prevention of Environmental Risks (PPRA) and Control of Occupational Health Medical ${ }^{16}$. However, there is still a strong attachment of these practices to the traditional occupational medicine and occupational health, which focuses on the observation of the most exposed events, acute illnesses, poisoning and accidents and disregards the illness process based on worker exposure to many determinants and conditioning factors of these diseases. Thus, it is necessary to include surveillance activities in occupational health, combined to monitoring of risk factors for these diseases and disorders related to work with the participation of workers, their social organizations and other health services for the maintenance of their health in work environments ${ }^{23}$.

Some considerations about the work accident record should be made. The issue of occupational accident communication is mandatory for workers in Labor Laws Consolidation regime; however its scope is rather narrow as this is obligatory only for formal workers, excluding, in addition to domestic workers, those in the informal, statutory and autonomous work. It is also important to consider is the underreporting of such accidents, in part by the little interest of the professionals responsible for recording the CAT, which favor the fulfillment of bureaucratic rules, but not the professional involvement the issue of accident ${ }^{24}$. However, it is understood that this underreporting occurs uniformly throughout the state,, not invalidating, thus, measures of statistical correlations found in this study.

It has been as important to the assessment of confounding variables (GDP per capita, FHP coverage and existence of hospitals in the city) in the model, because they are considered determinants of overall health status of the population, being this one of the reasons that led us to include them as adjustment variables in the multiple linear regression.

The results of this study point to the importance of spatial assessment of occupational accident rates and their relation to the cattle slaughter, variable "proxy" number of jobs in cattle activities in the Amazon biome, savanna and wetland Brazilian.

\section{CONCLUSION}

This study reinforces the evidence that cattle slaughter can be related to higher rates of respiratory occupational accidents in municipalities in the state of Mato Grosso, southern Brazilian Amazon.

Our results point to the importance of spatial assessment of morbidity due to occupational accidents and their relationship to the number of slaughtered cattle heads in the Brazilian Amazon and Pantanal biomes.

This work also indicates priorities for intersectoral actions of the Ministry of Labor and Employment, National Institute of Social Security, the Unified Health System, workers and their social organizations in order to extend the monitoring of the factors risk and protective actions of diseases and related health problems of labor in the production chain of cattle in the southern Brazilian Amazon. 


\section{REFERENCES}

1. Moreno G. Mato Grosso: policies and strategies of occupation. In: Moreno G, Souza TC, editors. Mato Grosso geography: territory, society, environment. Cuiabá: Entrelinhas; 2005. p. 34-51.

2. Macarini JP. The economic policy of the Medici government: 19701973. Nova Econ. 2005;15(3):53-92. http://dx.doi.org/10.1590/S010363512005000300003

3. Instituto Brasileiro de Geografia e Estatística. Agricultural census. Rio de Janeiro; 2006 [cited 2015 Jun 20]. Available from: www.ibge.gov.br.

4. Vasconcelos MC. Diseases related health work in meatpacking industry in the State of Mato Grosso. Cuiabá: Mato Grosso Federal University; 2008.

5. Rigotto RM. Environmental Health \& Worker's Health: a promising approach between the Green and the Red. Rev Bras Epidemiol. 2003;6(4):388-404. http://dx.doi.org/10.1590/S1415-790X2003000400013.

6. Instituto Brasileiro de Geografia e Estatística. Geosciences 2002-2008 [Internet]. Rio de Janeiro: IBGE [cited 2015 June 20]. Available from: http://downloads.ibge.gov.br/downloads_geociencias.htm

7. Brasil. Ministério da Previdência Social. nstituto Nacional do Seguro Social. Statistical yearbook of occupational accidents. Brasília: INSS; 2009.

8. Brasil. Ministério do Trabalho e Emprego. Relação Anual de Indicadores Sociais - RAIS 2009. Brasília; 2009.

9. Brasil. Ministério da Saúde. Departamento de Informática do SUS. Information in health [Internet]. Brasília [cited 2015 Jun 20]. Available from: http://tabnet.dataus.gov.br

10. Programa Educacional de Resistência às Drogas [Internet]. [cited 2014 Mar 10]. Available from: https: http://www.proerdbrasil.com.br/ oproerd/ oprograma.htm

11. Carvalho MSC, Cruz G, Oswaldo G, Correa, V. Area Data Analysis. In: Druck S, Carvalho MS, Câmara G, Monteiro AVM, editors. Spatial analysis of geographic data. Brasília: EMBRAPA; 2004.

12. Souza WV, Barcellos CC, Brito AM, Carvalho MS, Cruz OG, Albuquerque MF, et al. Empirical bayesian model applied to the spatial analysis of leprosy occurrence. Rev Saude Publica. 2001;35(5):474-80. PMid:11723520.

13. Machado LDOR. Deforestation in the Brazilian Amazon: colective action, governance and governability in boundary areas. Soc Estado. 2009;24:115-47.
14. Sarda SE, Ruiz RC, Kirtschig G. Juridical tutelage concerning the health of meat packing workers: public service considerations. Acta Fisiátrica. 2009;16(2):59-65.

15. Pardi MC, Santos IF, Souza ER, Pardi HS. Science, hygiene and meat technology. Goiânia: UFG; 2001.

16. Reis RS, Fernandes MM. Safety and occupational health: regulatory norms. São Caetano do Sul: Yendis; 2007.

17. Arima E, Barreto P, Brito M. Livestock in the Amazon: trends and implications for environmental conservation. Belém: Institute of Man and Environment in the Amazon; 2005.

18. Rivero S, Almeida O, Ávila S, Oliveira W. Livestock and deforestation: an analysis of the main direct causes of deforestation in the Amazon. Nova Econ 2009;19(1):41-66. http://dx.doi.org/10.1590/S0103-63512009000100003.

19. Instituto Brasileiro de Geografia e Estatística. Indicators of Sustainable Development: Brazil 2010. Rio de Janeiro; 2010.

20. Machado FS, Pereira LGR, Guimarães Jr R, Lopes FCF, Chaves AV, Campos $\mathrm{MM}$, et al. Methane emissions in livestock: concepts, methods of evaluation and mitigation strategies. Juiz de Fora: EMBRAPA; 2011. 92 p.

21. Silva JM, Novato-Silva E, Faria HP, Pinheiro TMM. Agrotóxico e trabalho: uma combinação perigosa para a saúde do trabalhador rural. Cien Saúde Colet. 2005 Dec;10(4):891-903. http://dx.doi.org/10.1590/S141381232005000400013 .

22. Marques APP. Productive restructuring and the reallocation of work and employment: a survey of the "new" forms of social inequality. Cien Saúde Colet. 2013;18(6):1545-54. http://dx.doi.org/10.1590/S1413-81232013001400007. PMid:23752522.

23. Kelly-Santos A, Rozemberg B. Construction workers' reactions to educational materials: a debate on relations between health and work. Cad Saúde Pública. 2006;22(5):975-85. PMid:16680350.

24. Marziale MHP, Rodrigues CM. The scientific production on occupational accidents with needlestick materials among members of the nursing team. Rev Lat Am Enfermagem. 2002;10(4):571-7. http://dx.doi.org/10.1590/ S0104-11692002000400015. PMid:12592859.

Received on: June 21, 2015 Accepted on: Sept. 14, 2015 